\title{
Chlorophyll content in beet cv. Early Wonder under nitrogen fertilization
}

\author{
Patrícia Ferreira da Silva ${ }^{1 *}$ (D), Rigoberto Moreira de Matos ${ }^{2}$, Mariana de Oliveira Pereira ${ }^{2}$, \\ Vitória Ediclécia Borges ${ }^{2}$,José Dantas Neto², Vera Lúcia Antunes de Lima²
}

10.1590/0034-737X201966060007

\begin{abstract}
This study aimed to evaluate the effects of doses of nitrogen fertilizer in association with types of basal dressing fertilizers on the physiological characteristics of beet cultivar Early Wonder in a protected environment. The experiment was conducted in safe environment at the Federal University of Campina Grande, using a randomized block design with three replications and a $5 \times 3$ factorial scheme, in five doses of nitrogen $\left(0,50,100,150\right.$ and $\left.200 \mathrm{mg} \mathrm{dm}^{-3}\right)$ applied through fertigation, and three types of basal dressing fertilizers (unfertilized soil, earthworm humus and earthworm humus + NPK). At 45 and 90 days after transplanting (DAT), it was determined the chlorophylls a, b, total chlorophylls, carotenoids and SPAD index. Organo-mineral fertilizer (earthworm humus + NPK) provides greater efficiency for the photosynthetic pigments when compared with organic fertilizer (earthworm humus) and without fertilization (control). The increase of nitrogen dose up to $200 \mathrm{mg} \mathrm{dm}^{-3}$ is the one which contributes most to the increment of chloroplastid pigments. Nutrients were absorbed by the plants and the humus and humus + NPK treatments supplied the nutritional demands during the beet cultivation cycle.
\end{abstract}

Keywords: Beta vulgaris L.; nitrogen; organic fertilization; intensity of green color.

\section{INTRODUCTION}

The beet (Beta vulgaris L.) is an olive with a tuberous root, originated in Europe, and a member of Chenopodiaceae family (Filgueira, 2008). According to Sediyama et al. (2011), this vegetable is earning space and economical importance in Brazil, being one of the ten main vegetable produced in the country. It has a high nutritional value sticking out among tuberous roots for its nutritional composition, which is rich in sugar, antioxidants, betacarotene, B-complex vitamins, and some nutrients as potassium, sodium, iron, copper, and zinc (Trani et al. 2013).

Trani et al. (2013) points out that tuberous root is the storage organ of beet. The storage of hypocotyl-radicle axis and the upper portion of the primary root swell and have their composition and development influenced by the nitrogen fertilization (Filgueira, 2008).

Nitrogen either applied as mineral or organic fertilizer is considered an important component for plants, being one of the crucial compounds for growth, development and yield of plants, since it is constituent of chlorophyll, nitrogenous bases of the nucleotides, amino acids, proteins and compounds of secondary metabolism (Taiz \& Zeiger, 2013).

According to Singh et al. (2010), organic fertilization in association with mineral fertilization increase the production efficiency of crops resulting in physical, chemical and biological benefits for plants and soil. It improves the physical structure of plant and increases the

Submitted on October 31st, 2018 and accepted on October $29^{\text {th }}, 2019$.

${ }^{1}$ Universidade Federal de Campina Grande, Centro de Tecnologia e Recursos Naturais, Campina Grande, Paraíba, Brazil. patrycyafs@yahoo.com.br

${ }^{2}$ Universidade Federal de Campina Grande, Departmento de Engenharia Agrícola, Campina Grande, Paraíba, Brazil. rigobertomoreira@gmail.com; marianapereira.agri@gmail.com; edicleciaborges@gmail.com; zedantas1955@gmail.com; antuneslima@gmail.com

*Corresponding author: patrycyafs@yahoo.com.br 
capacity of retaining water and nutrients due to greater variety of microorganisms and their activity in soil.

Marenco \& Lopes (2009) argue that the application of nitrogen helps to increase production elevating chlorophyll content in crops, since $70 \%$ of nitrogen of leaves is in the chloroplasts taking part of synthesis and molecules structures of chlorophyll. Chlorophyll content is directly related to the photosynthetic rate, nitrogen concentration in plant, and the productivity of crops (Silva et al., 2012).

Taiz \& Zeiger (2013) state that the presence of chlorophyll in plants is vital to their development. However, when chlorophyll is restricted to low concentration the production and growth of cultivars are directly affected. This fact is associated with nitrogen availability in soil, since it is a basic component of amino acids necessary for chlorophyll synthesis, which influences the process.

There are a variety of methods that determine chlorophyll content in plants, among which the portable chlorophyll meter is known by its non-destructive method that allows a quickly evaluation of nitrogen concentration in plants leaves, contributing to reduce the usage of nitrogen fertilizers. It is important to know chlorophyll content to deal correctly with fertilization and to ensure that the crops absorb it (Santana et al., 2010; Araujo et al., 2013).

A range of studies have correlated nitrogen content in leaves with relative chlorophyll rate and nutritional status of plants (Pôrto et al., 2011; Persegil, 2012; Leonardo et al., 2013; Marenco et al., 2014). However, few studies have associated and evaluated the application of nitrogen through fertigation and basal dressing fertilization on the physiological characteristics of beet.

The beet is a very demanding crop in nutritional terms, especially nitrogen, it requires a balanced fertilization capable of replacing the nutrients extracted by the crop, avoiding soil depletion. In this sense, studies on nitrogen fertilization associated with types of foundation fertilization, especially organic fertilization, are fundamental for producers' planning of actions.

Considering these facts, this study aimed to evaluate the effects of doses of nitrogen fertilizers associated with basal dressing fertilizers on the physiological characteristics of beet cultivar Early Wonder in a protected environment.

\section{MATERIAL AND METHODS}

The study was carried out from June to August of 2016, in a greenhouse, at the Department of Agricultural Engineering (DEAg) of the Federal University of Campina Grande, in the municipality of Campina Grande, Paraiba, Brazil. The greenhouse covers 15 meters long, 10 meters wide and 3 meters high with a coverage of a low density polyethylene, which has thickness of 150 microns and sidewalls revested with shading cloth.

The data concerning temperature and relative humidity were observed during the experiment and collected through a digital thermo hygrometer that was installed in the greenhouse (Figure 1).

The soil used in the experiment was classified as sandy loam soil, whose physical and chemical characteristics, with a depth of $0.0-0.2 \mathrm{~m}$, are shown in the table below, according to Embrapa methodology (2013).

Fertile and chemical properties of earthworm humus analysis used in the experiment are shown in the table 2 below:

Treatments were combined as the following: five doses of nitrogen fertilizers applied through fertigation $(0$, $50,100,150$ and $200 \mathrm{mg}$ of nitrogen per $\mathrm{dm}^{-3}$ of soil) and three types of basal dressing fertilizers: soil without fertilization (control), soil fertilized with organic earthworm humus, and soil fertilized with earthworm + NPK using urea $45 \%$, single superphosphate $\left(18 \% \mathrm{P}_{2} \mathrm{O}_{5}, 16 \% \mathrm{Ca}\right.$ and $8 \% \mathrm{~S}$ ), and potassium chloride $\left(60 \% \mathrm{~K}_{2} \mathrm{O}\right)$ (organo-mineral). The potassium and phosphorus dose used were, respectively, 75 and $100 \mathrm{mg}$ per pot. Urea was used as a source of nitrogen, corresponding to $(0.0,0.7,1.4,2.1$ and $2.8 \mathrm{~g}$ of $\mathrm{N}$ per pot) and the total dose applied according to the methodology proposed by Silva \& Silveira (2012) in three applications: the first at 20, the second at 40 and the third at 60 DAT.

It was used a randomized block design with three replications and a $5 \times 3$ factorial scheme. To carry out the experiment, 45 pots with a cylindrical shape and capacity of $20 \mathrm{~L}$ were placed in a space of $0.5 \mathrm{~m}$ between plants and 1.0 between rows. Each experimental unit was composed with a pot containing a hole in the bottom. The pots were filled with a $1 \mathrm{~cm}$ layer of crushed stone $\left(\mathrm{n}^{\mathrm{o}} 1\right)$, covered with a geotextile fabric to facilitate drainage and filled with around $14 \mathrm{dm}^{3}$ of soil.

The beet cultivar Early Wonder is one of the most cultivated by small horticulturists in the Green Belts, located in the northeast of Brazil. The seedings were produced in a polyethylene tray with 128 cells and commercial substrate. Transplanting was conducted at 20 days after sowing, placing two seedlings per pot.

A drip irrigated system was adopted using pressure compensating emitters, nominal flow rate of $2.3 \mathrm{~L} \mathrm{~h}^{-1}$ connected to an irrigation tube $(16 \mathrm{~mm}$ polyethylene tubing), which were connected to butterfly valves at their tips facilitating the application of nitrogen doses through fertigation in each treatment. A hydrometer was attached to the tip of the control head of water quantity in the lateral tubes, since it is necessary to control management when irrigating through fertigation. 
Pumping was performed using a centrifugal pump motor $0.5 \mathrm{CV}$. In order to avoid particle matters in the system, it was used a screen filter 1" with a flow capacity of $5 \mathrm{~m}^{3} \mathrm{~h}-$ ${ }^{1}$, superior than diameter of emitters.

Irrigation interval treatments were scheduled in 2 days and the irrigation depth was determined by the crop evapotranspiration (ETc). It was analyzed drainage in lysimeters, which indicated an average balance of water in and out of the system, maintaining humidity values close to field capacity values during the crop cycle, as in the equation 1 :

$E T c=I-D$

ETc $=$ crop evapotranspiration in $\mathrm{mm} \mathrm{day}^{-1} ; \mathrm{I}=$ irrigation depth in $\mathrm{mm}_{\text {day }}{ }^{-1}$; D: drainage lysimeter in $\mathrm{mm}_{\text {day }}{ }^{-1}$
At 45 and 90 DAT, chlorophyll a and b and total chlorophyll, carotenoids and SPAD index of beet Early Wonder were evaluated.

Measurements were conducted using a chlorophyll portable meter (SPAD-502, Minolta, Japan), between 9:00 AM and 9:30 AM. Each SPAD index was analyzed five times in the central leaf blade of the plots, being represented by the average treatments.

Chlorophyll contents were determined in laboratories with the same leaves that were analyzed the SPAD index. To carry out the procedure, leaf discs with $0.77 \mathrm{~mm}$ diameter were obtained with a puncher, which perforated the leaf blade between the tip and the central nervure, weight samples varying between $50-200 \mathrm{~g}$.
A

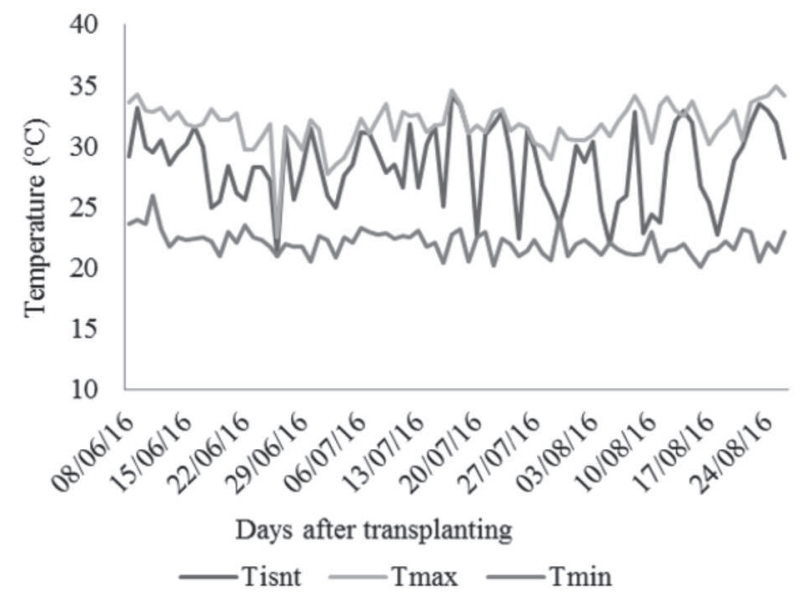

B

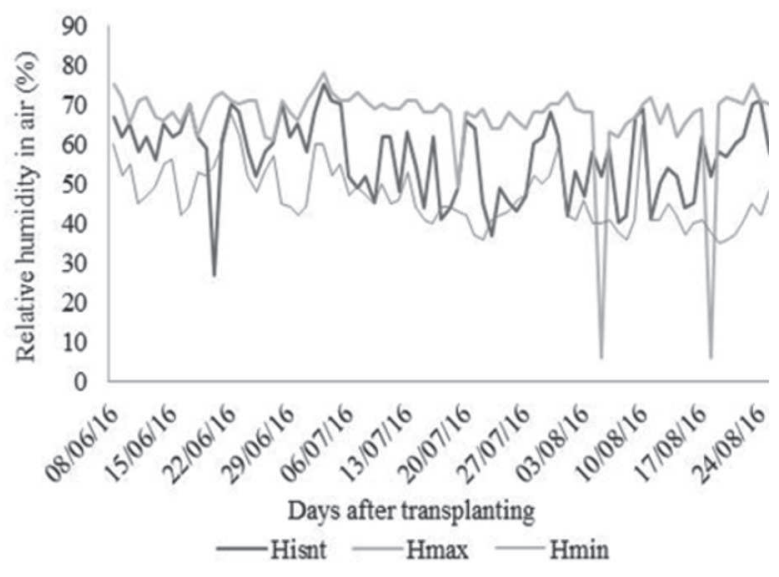

Figure 1: Instantaneous, maximum and minimum temperature (A) and relative humidity in air (B) observed during the experimental period for cv. 'Early Wonder' (Beta vulgaris L). Campina Grande, PB, Brazil.

Table 1: Physical-chemical characteristics of the soil used in the experiment.Campina Grande, PB, Brazil

\begin{tabular}{|c|c|c|c|c|c|c|c|c|}
\hline \multirow{2}{*}{ pH } & $\mathbf{O M}$ & $\mathbf{P}$ & $\mathbf{K}^{+}$ & $\mathbf{N a}^{+}$ & $\mathrm{Ca}^{2+}$ & $\mathbf{M g}^{2+}$ & $\mathbf{A l}^{3+}$ & $\mathbf{H}$ \\
\hline & $(\%)$ & mg 100g ${ }^{-1}$ & \multicolumn{6}{|c|}{$\operatorname{mmol}_{c} \mathrm{dm}^{-3}$} \\
\hline \multirow[t]{4}{*}{5.9} & 0.65 & 1.43 & 0.14 & 0.07 & 1.90 & 0.66 & 0.20 & 1.88 \\
\hline & \multicolumn{2}{|c|}{ Density } & Sand & & Silt & & Clay & \\
\hline & \multicolumn{2}{|c|}{$\left(\mathrm{g} \mathrm{cm}^{-3}\right)$} & \multicolumn{5}{|c|}{$(\%)$} & \\
\hline & \multicolumn{2}{|c|}{1.39} & 74.70 & & 16.11 & & 9.19 & \\
\hline
\end{tabular}

${ }^{*} \mathrm{pH}=$ hydrogenionic potential, $\mathrm{OM}=$ organic matter, $\mathrm{P}=$ phosphorus, $\mathrm{K}=$ potassium, $\mathrm{Na}=$ sodium, $\mathrm{Ca}=$ calcium, $\mathrm{Mg}=$ magnesium, $\mathrm{Al}=$ aluminium and $\mathrm{H}=$ hidrogen.

Table 2: Organic fertilizer characteristics (earthworm humus) used in the experiment. Campina Grande, PB, Brazil

\begin{tabular}{|c|c|c|c|c|c|c|c|c|c|c|c|}
\hline \multirow{2}{*}{ pH } & \multirow{2}{*}{$\frac{\mathrm{OM}}{\mathrm{g} \mathrm{kg}^{-1}}$} & \multirow{2}{*}{\multicolumn{2}{|c|}{$\frac{P}{\mathrm{mg} \mathrm{dm}^{-3}}$}} & $\mathrm{Na}^{+}$ & $\mathrm{Ca}^{2+}$ & $\mathbf{M g}^{2+}$ & $\mathbf{A l}^{3+}$ & SB & CEC & $\mathbf{V}$ & $\mathbf{m}$ \\
\hline & & & & \multicolumn{6}{|c|}{$\mathrm{cmol}_{\mathrm{c}} \mathrm{dm}^{-3}$} & \multicolumn{2}{|c|}{$\%$} \\
\hline 6.9 & 73.1 & 469.3 & 656.0 & 0.9 & 13.2 & 1.0 & 0.0 & 18.9 & 20.8 & 91.2 & 0.0 \\
\hline
\end{tabular}

Rev. Ceres, Viçosa, v. 66, n.6, p. 460-469, nov/dec, 2019 
Chlorophyll a, b and total chlorophyll contents and carotenoids were quantified by extracting pigments from the fresh leaf samples. They had their weight measured, crushed and transformed into petri dash in a slightly luminous place, being stored in recipients containing $6 \mathrm{~mL}$ of $80 \%$ acetone kept in the dark under refrigeration over 72 hours. After that, the supernatants with extracted pigments were collected and the absorbances were read. It was used a spectrophotometer, wavelength at $470 \mathrm{~nm}$ (carotenoids), $647 \mathrm{~nm}$ (chlorophyll b), $663 \mathrm{~nm}$ ( chlorophyll a) and 80\% acetone used for the blank reading. Milligrams of chlorophyll per gram fresh weight of leaf tissue were calculated based on the methodology proposed by Whitham et al. (1971).

The statistical F-test was applied to the samples, significance level at $5 \%$ and $1 \%$, relationating the samples whenever the interaction was considerable. The quantitative factor of nitrogen doses was statistically analysed through polynomial regression (linear and squared) and the types of basal dressing fertilizers used Tukey's test at $5 \%$ for comparing the means with the Sisvar computer program (Ferreira, 2014).

\section{RESULTS AND DISCUSSION}

An overview of variance analysis for chlorophyll a, b and total chlorophylls, carotenoids, and SPAD index of beet, due to nitrogen doses applied through fertigation and with the types of basal dressing fertilizers, at 45 and 90 DAT are shown, respectively, in the tables 3 and 4 below:

Individual effects of the types of basal dressing fertilizers and nitrogen doses applied through fertigation presented significant effect when using the F-test at $1 \%$ level of probability for all the variables of beet that were evaluated at 45 and 90 DAT (Tables 3 and 4).

Trani et al. (2005) analysed the effect of nitrogen doses applied as side dressing and obtained similar results to the present study. It was concluded that there was a linear and positive relationship between nitrogen content in leaves and the applied nitrogen dose. Chlorophyll a content was significantly influenced by individual effects of the types of basal dressing fertilizers and nitrogen doses at 45 and 90 DAT (Figure 2).

There was a significant result for the variable chlorophyll a in beet plants when fertilized at 45 and 90 days, using Tukey's test $\mathrm{p}<0.05$ (Figure 2 A). Earthworm humus + NPK fertilizer promoted the greatest increments for the chlorophyll a content in beet plants, followed by earthworm humus fertilizer. It happened due to the greater amount of nitrogen in humus + NPK when compared to the other treatments.

Independent of the fertilizers applied, it was realized that chlorophyll a contents at 45 DAT were higher than the contents at 90 DAT (Figure 2A). This indicates that after the 45 DAT beet the response of the crop to $\mathrm{N}$ is lower when compared to the beginning of vegetative development, which may have contributed to the chlorophyll content in leaves from 45 to 90 DAT stabilizes.

According to Taiz \& Zeiger (2013), chlorophyll is strictly related to the nutritional status of plants. The quantity of chlorophyll in plant leaves have been used to evaluate the nutritional status of crops, that is, the increase of nutritional availability, in particular of $\mathrm{N}$ and $\mathrm{Mg}$ (main components of the porphyrin ring of chlorophyll molecule).

Costa et al. (2008) argues that chlorophyll a increased when the concentration of organic fertilizer was raised in plants. On the other hand, the treatment without fertilization (control) made the plants become yellowish when compared to the others. The same results were found in the present study.

In relation to chlorophyll a, considering the doses of nitrogen applied through fertigation, the mathematical model that best met the needs was the linear on both at 45 and 90 DAT (Figure 2B). The maximum results for chlorophyll a, depending on the fertigated doses of

Table 3: Overview of variance analysis for chlorophyll a, b and total chlorophylls, carotenoids, and SPAD index at 45 DAT for cv. 'Early Wonder' (Beta vulgaris L).

\begin{tabular}{lcccccc}
\hline & & \multicolumn{5}{c}{ Values of mean squares } \\
\cline { 3 - 7 } Source of Variation & GL & \multicolumn{5}{c}{$\mathbf{4 5}$ days after transplanting (DAT) } \\
\cline { 3 - 7 } & & Chlorophyll a & Chlorophyll b & Chlorophyll total & Carotenoids & SPAD \\
\hline Types of Fertilizers (A) & 2 & $1.68^{* *}$ & $0.41^{* *}$ & $3.76^{* *}$ & $0.12^{* *}$ & $1395.42^{* * *}$ \\
Doses of Nitrogen (N) & 4 & $0.43^{* *}$ & $0.29^{* * *}$ & $1.43^{* *}$ & $0.17^{* *}$ & $326.48^{* *}$ \\
A ${ }^{* *}$ & 8 & $0.08^{\text {ns }}$ & $0.01^{\text {ns }}$ & $0.15^{\text {ns }}$ & $0.01^{\text {ns }}$ & $19.10^{\text {ns }}$ \\
Block & 2 & 0.28 & 0.06 & 0.60 & 0.01 & 45.40 \\
Residue & 28 & 0.06 & 0.20 & 0.14 & 0.06 & 7.03 \\
\hline CV $(\%)$ & - & 32.40 & 29.38 & 29.89 & 24.17 & 7.10 \\
\hline Average Overall & - & 0.80 & 0.49 & 1.29 & 0.32 & 37.34 \\
\hline
\end{tabular}

Note: ${ }^{* *},{ }^{*}$ significant at 1 and $5 \%$ respectively; ${ }^{\text {ns }}$ non-significant. 
nitrogen, were obtained with a dose of $2.8 \mathrm{~g}$ of nitrogen per pot, corresponding to 1.07 and $0.95 \mathrm{mg} \mathrm{g}^{-1}$ fresh mass (MF) at 45 and 90 DAT, respectively. It further noted that, the increase of chlorophyll a with the increment of nitrogen per unit presented 0.19 and $0.16 \mathrm{mg} \mathrm{g}^{-1}$ of $\mathrm{MF}$ of beet at 45 and 90 DAT.

Barreto et al. (2013), when studying the chlorophyll content in beet, obtained values higher than $30 \mathrm{mg} \mathrm{g}^{-1}$ in the treatment with organic and mineral fertilization. This value is higher than the value found in this study, which might be related to the increase doses through organic fertilization that allowed plants assimilate nitrogen and magnesium, since they share the chlorophyll molecule (Ferreira et al., 2012).

Chlorophyll b content was significantly influenced by individual effects of the types of basal dressing fertilizers (A) and by nitrogen doses at 45 and 90 DAT (Figure 3).

Chlorophyll b variable presented statistical differences by Tukey's test $(p<0.05)$ when different types of basal dressing fertilizers were applied at 45 and 90 DAT. The treatments using earthworm humus and earthworm humus + NPK did not showed statistical differences at 45 DAT. However, it is important to highlight that, in absolute values, the treatment with earthworm + NPK was higher than the treatment with only earthworm, both at $45\left(0.63 \mathrm{mg} \mathrm{g}^{-1} \mathrm{MF}\right)$ and 90 DAT (0.42 $\left.\mathrm{mg} \mathrm{g}^{-1} \mathrm{MF}\right)$ (Figure 3A).

At 90 DAT the treatments presented statistical differences, however the treatment with earthworm humus did not differ from the organo-mineral treatment with earthworm humus + NPK (Figure 3A). This factor might be related to low chlorophyll $b$ variation when compared to chlorophyll a. Decreasing tendency of chlorophyll a in mature plants must be taking into account, since at 90 DAT beet plants were mature. Thus, leaf senescence (occurs in all vegetables), causes loss of green color and, consequently, reduces chlorophyll content (Taiz \& Zeiger, 2013).

Table 4: Overview of variance analysis for chlorophyll a, b and total chlorophylls, carotenoids, and SPAD index at 90 DAT and SPAD index at 45 DAT. for cv. 'Early Wonder' (Beta vulgaris L). Campina Grande, PB, Brazil

\begin{tabular}{lcccccc}
\hline & & \multicolumn{5}{c}{ Values of mean squares } \\
\cline { 3 - 7 } Source of Variation & GL & \multicolumn{5}{c}{ 90 days after transplanting (DAT) } \\
\cline { 3 - 7 } & & chlorophyll a & chlorophyll b & chlorophyll total & carotenoids & SPAD \\
\hline Types of Fertilizers (A) & 2 & $1.39^{* *}$ & $0.03^{* *}$ & $1.81^{* *}$ & $0.04^{* *}$ & $98.35^{* * *}$ \\
Doses of Nitrogen (N) & 4 & $0.32^{* *}$ & $0.09^{* *}$ & $0.75^{* *}$ & $0.05^{* *}$ & $538.54^{* *}$ \\
A $*$ N & 8 & $0.08^{\text {ns }}$ & $0.04^{\text {ns }}$ & $0.08^{\text {ns }}$ & $0.02^{\text {ns }}$ & $26.71^{\text {ns }}$ \\
Block & 2 & 0.02 & 0.12 & 0.07 & 0.01 & 38.54 \\
Residue & 28 & 0.04 & 0.07 & 0.07 & 0.05 & 29.91 \\
\hline CV $(\%)$ & - & 29.14 & 22.12 & 24.90 & 29.72 & 13.14 \\
\hline Average Overall & - & 0.72 & 0.38 & 1.11 & 0.24 & 41.61 \\
\hline
\end{tabular}

Note: ${ }^{* *},{ }^{*}$ significant at 1 and $5 \%$ respectively; ${ }^{\text {ns }}$ non-significant.

(A)

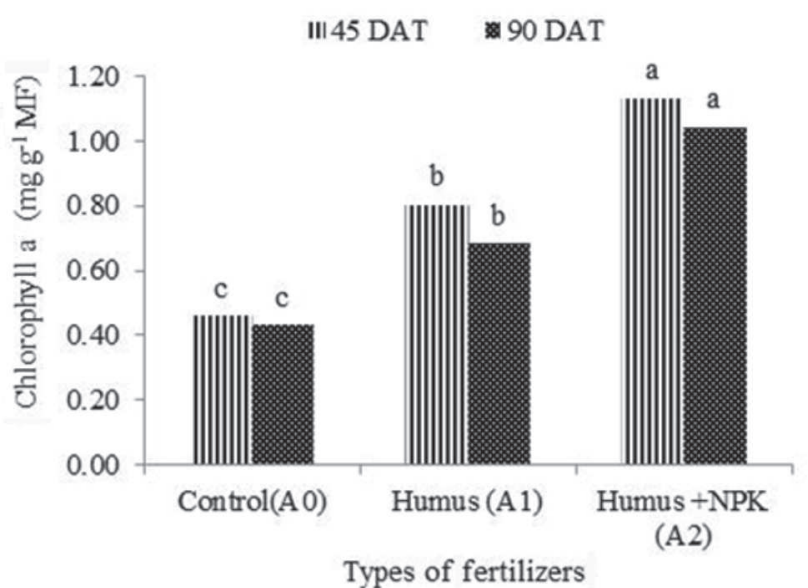

(B)

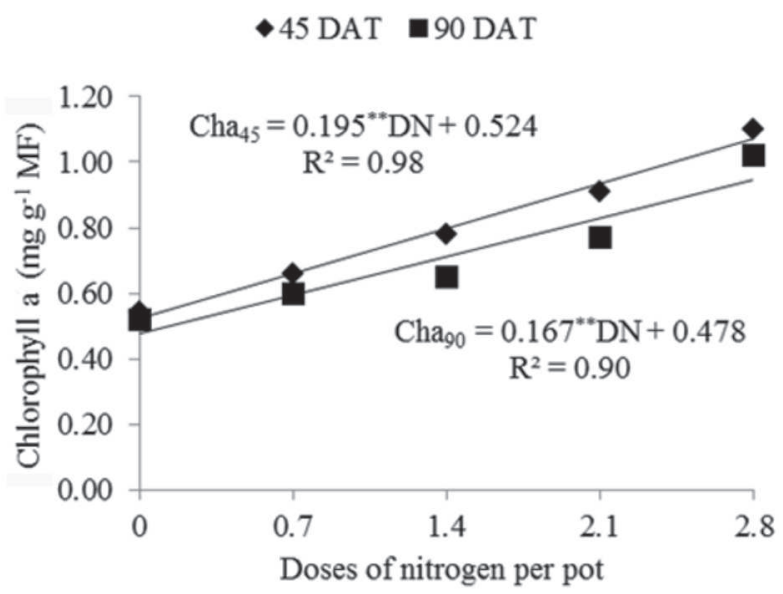

Figure 2: Chlorophyll a content in beet plants depending on the types fertilizers (A) and nitrogen doses applied through fertigation (B) at 45 and 90 DAT and SPAD index at 45 DAT for cv. 'Early Wonder' (Beta vulgaris L). Campina Grande, PB, Brazil. Equal letters do not differ statistically according to Tukey's test $(\mathrm{p}<0.05)$. 
The doses of nitrogen fertilization, applied through fertigation, ocasionated a great effect on chlorophyll " $b$ ". The increase of nitrogen up to $2.8 \mathrm{~kg}$ per pot resulted in the increment of chlorophyll b content (Figure $3 \mathrm{~B}$ ).

Positive correlation was observed between the applied nitrogen dose and chlorophyll content $\mathrm{b}$ at both 45 and 90 DAT, respectively (Figure 3B). The positive correlation observed between chlorophyll content and applied nitrogen rates shows that the photosynthetic system components may, due to the nitrogen content in the leaf tissue, reflect the photosynthetic adaptation of the plants. This fact may favor the obtaining of relative chlorophyll indices due to the likelihood of response to nitrogen fertilization, which is important information to guide producers in deciding on the need to apply nitrogen fertilizer.

The types fertilizers and nitrogen doses at 45 and 90 DAT influenced in a positive way the total chlorophyll content (Figure 4). Chlorophyll a is a pigment used to conduct the photochemical stage, while chlorophyll $\mathrm{b}$ and carotenoids help to absorb light and in transfer radiant energy to the reaction centres. In this way, chlorophyll content contributes to verify the demands of nitrogen in plants (Streit et al., 2005; Silva et al., 2014).

The results of chlorophyll a, b and total chlorophylls were the same, in which humus + NPK (organo-mineral) promoted greater average at $45\left(1.77 \mathrm{mg} \mathrm{g}^{-1}\right.$ of MF) and 90 DAT (1.47 $\mathrm{mg} \mathrm{g}^{-1}$ of MF) when compared to the treatment using only humus (Figure 4A).

Leonardo et al. (2013) carried out a study to analyse the effect of litter of broiler (organic nitrogen source) and urea (mineral nitrogen source) applied through top dressing. The results showed that mineral fertilizer significantly contributed for chlorophyll content with a maximum value at $0.25 \mathrm{mg} \mathrm{g}^{-1}$ with a dose of $19.4 \mathrm{~g} \mathrm{plant}^{-1}$. In this case, the results were not the same for the present study, since the total chlorophylls were higher to organo-mineral treatment, which might be associated with nutritional demand.

Total chlorophyll contents gradually increased at 45 and 90 DAT with the rise of nitrogen doses. It promoted the greatest values when $2.8 \mathrm{~g}$ were applied per pot, corresponding to 1.78 and $1.46 \mathrm{mg} \mathrm{g}^{-1}$ of $\mathrm{MF}$, with determination coefficient valuing $\mathrm{R}^{2}$ of 0.98 e 0.94 , respectively (Figure 4B).

Barreto et al. (2013), in order to evaluate the chlorophyll content in beet cultivar Early Wonder and Itapuã, used nitrogen mineral fertilizer (calcium nitrite), which was applied through side dressing. It was found that the raise of doses in soil increased chlorophyll content. Pôrto et al. (2011) also took a study with increasing doses of mineral nitrogen fertilizer (ammonium sulfate) using zucchini cultivar caserta and concluded that it promoted gains for the chlorophyll content. These studies reaffirm the result found in this research.

Individual effects of the application of the types of basal dressing fertilizers and doses of nitrogen influenced, in a positive way, the carotenoids at 45 and 90 DAT (Figure 5).

Carotenoids showed considerable statistical differences with Turkey test $(\mathrm{p}<0.05)$ at 45 and 90 DAT. Organo-mineral treatment (earthworm humus + NPK) was the one which promoted the greatest increment for carotenoid pigment in beet leaves $\left(0.40 \mathrm{mg} \mathrm{g}^{-1}\right.$ of fresh mass) at 45 DAT.

Carotenoids are fundamental to the photosynthesis process, as they can perform two distinct functions: light
(A)

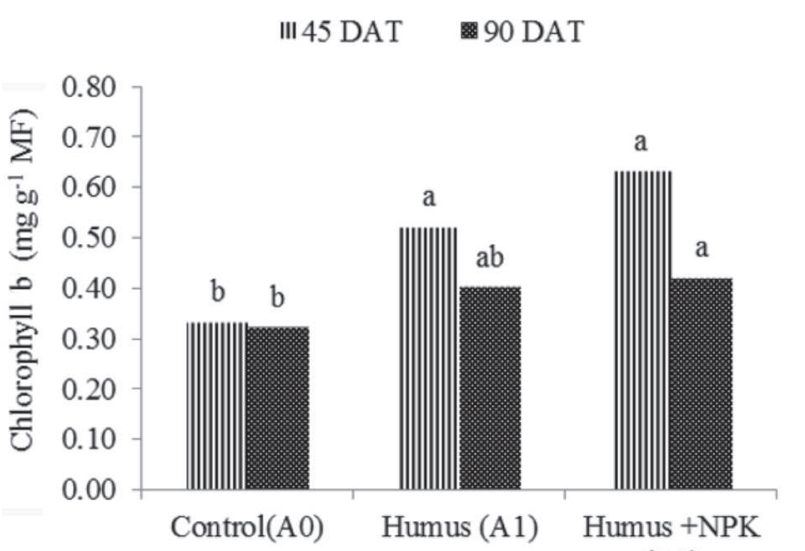

Types of fertilizers

(A2)

Figure 3: Chlorophyll b content in beet plants depending on the types fertilizers (A) and on the doses of nitrogen fertilization applied through fertigation (B) at 45 and 90 DAT and SPAD index at 45 DAT. for cv. 'Early Wonder' (Beta vulgaris L). Campina Grande, PB, Brazil. Equal letters do not differ statistically according to Tukey's test ( $p<0.05)$.
(B)

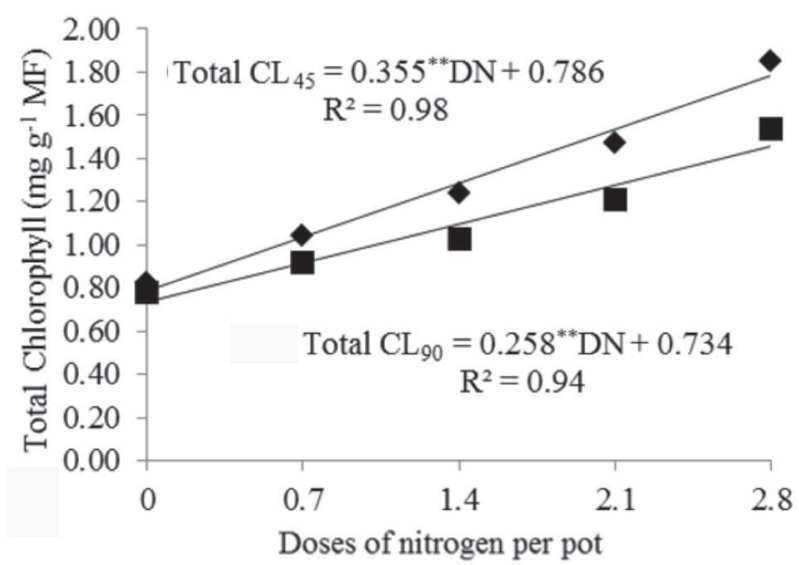


absorption in light-collecting complexes acting as accessory pigments and exerting photoprotective action of the photochemical apparatus, predicting photo-oxidative damage to chlorophyll molecules (Taiz \& Zeiger, 2013). In this sense, it is of fundamental importance to fertilize in a balanced way, especially with the use of organic fertilizers, favoring the supply of nutrients to the plants in order to contribute to the synthesis of these pigments.

Figueiredo Neto et al. (2011) carried out a study in order to identify the influence of organic compound on carrot roots and concluded that the treatment promoted the greatest gains for carotenoids, with values at $0.8 \mathrm{mg} \mathrm{g}$ ${ }^{1}$ of pulpe. These results are higher than the ones found in the present study.
Armond et al. (2016) states that humus is an important source of energy and nutrients in developing groups of organisms, especially microorganisms. When they decompose, they continually release $\mathrm{CO}_{2}, \mathrm{NH}_{4}^{+}$, íons of $\mathrm{P}$, $\mathrm{S}$ and micronutrients that are essential for the life cycle of vegetables, being directly related to photosynthesis and carotenoids formation as the same as to tuberculosis roots formation.

According to Spagnol et al. (2006), carotenoids are responsables for the reddish color in beet roots. They facilitate the vitamin A activity, that is, when food rich in carotenoids is swallowed by human beings, it is transformed in vitamin A. This is one of the most important sources for human organisms, which can be found in beet.
(A)

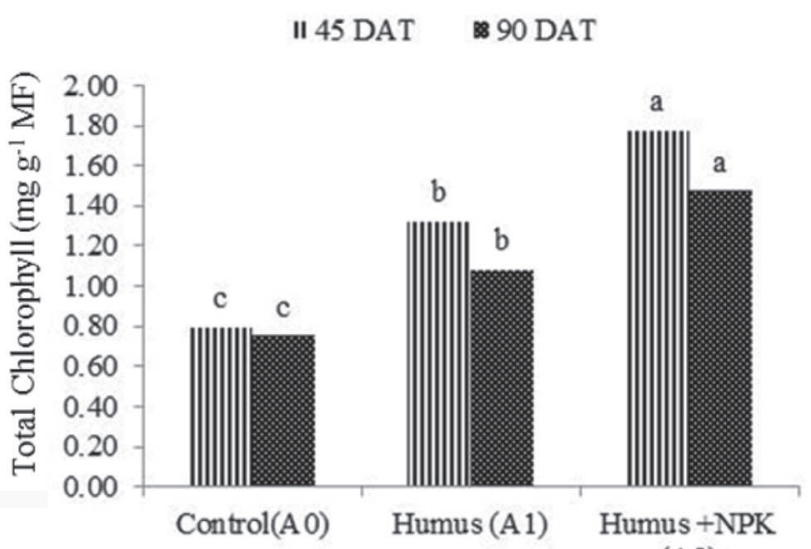

(A2)

Types of fertilizers

Figure 4: Total chlorophyll content in beet plants the types fertilizers (A) and nitrogen doses applied through fertigation (B) at 45 and 90 DAT and SPAD index at 45 DAT. for cv. 'Early Wonder' (Beta vulgaris L). Campina Grande, PB, Brazil. Equal letters do not differ statistically according to Tukey's test $(\mathrm{p}<0.05)$.

(A)

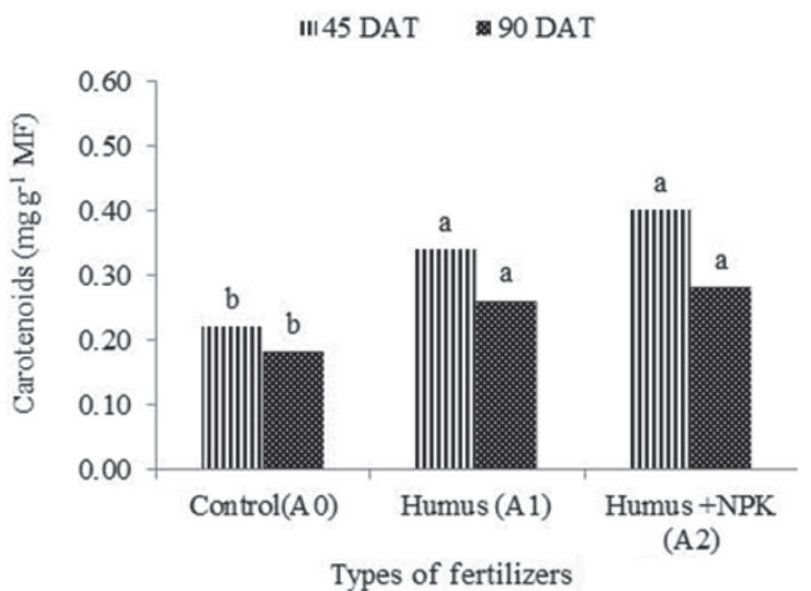

(B)

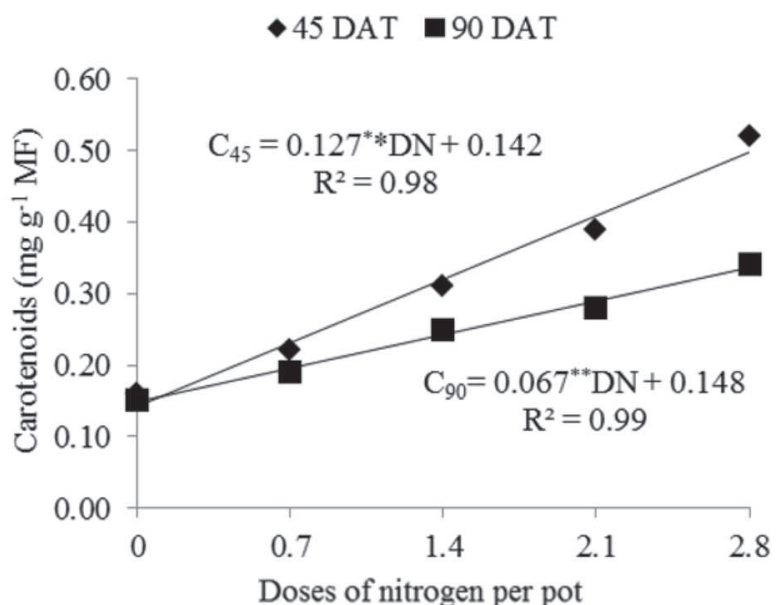


Linear math model was the one which best suited to the particular effect of nitrogen doses in carotenoids. As the dosage of nitrogen increased, carotenoids content continually raised. The greatest values of carotenoids were observed when a dose of 2.8 of $\mathrm{N}$ was applied per pot, corresponding to 0.49 e $0.33 \mathrm{mg} \mathrm{g}^{-1} \mathrm{MF}$, coefficient $\mathrm{R}^{2}$ of 0.98 (45 DAT) and 0.99 (90 DAT), respectively (Figure 5B).

During photosynthesis, carotenoids can absorb radiation in capturing light acting as accessory pigments exercising an activity photoprotective of photochemical apparatus and also preventing oxidative damage in chlorophyll molecules (Cavalcante et al., 2011).

There was a decrease of chloroplastid pigments (chlorophyll a, b, total chlorophylls and carotenoids) at 90 DAT when compared to the same pigments at 45 DAT. It might be related to senescence of the crop. According to Tivelli et al. (2011), the best intensity of nutrient absorption of beet occurs at 60 days after sowing and until 80 days the crop intensely develops.

Analysis of the intensity of green color in leaves (represented in SPAD index), was significantly influenced by individual effects of the types of basal dressing fertilizers and nitrogen doses at 45 and 90 DAT (Figure 6).

SPAD index showed significant effects $(\mathrm{p}<0.05)$ at 45 and 90 DAT for the treatment without fertilization (control) and for the treatment with humus and humus + NPK (Figure 6A). Plants that were fertilized with either organic or organo-mineral fertilizers indicated higher SPAD index than the plants without fertilization (control). Despite the treatments with humus and humus + NPK did not show any differences between them at 90 DAT, the last one presented the greatest absolute value for green color intensity (43.37). Leonardo et al. (2013) obtained similar results to this study using poultry litter as organic fertilizer.

(A)

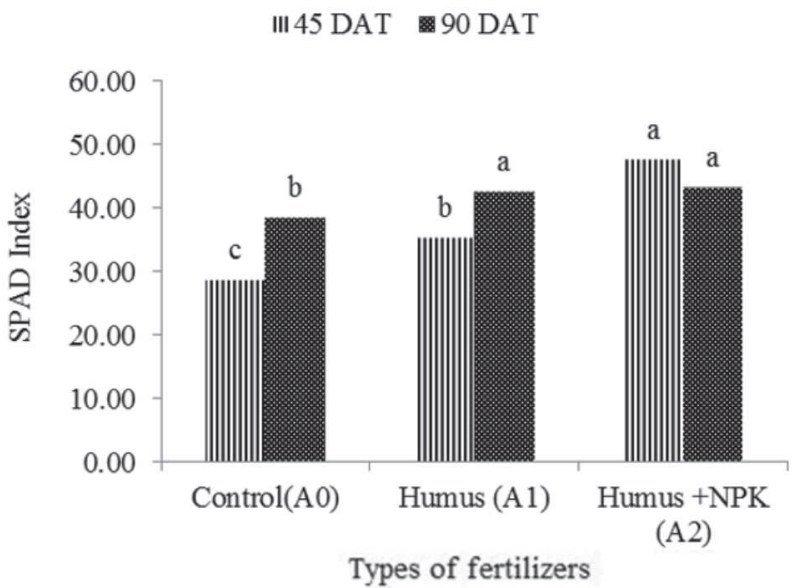

Bonfim-Silva et al. (2015) carried out a study with doses of vegetal ashes in radish and obtained SPAD index valuing at 44,70 which are closer to the results found in the present study. This index is related to chlorophyll contents in leaves and the nutritional evaluation of plants with rich nitrogen compounds, for example, the organic compound (Bonfim-Silva \& Monteiro, 2010).

Sant'Ana et al. (2010) states that SPAD index or clorophylometer enables to estimate in a quick, cheap, and non-destructive way, the concentration of nitrogen in plant leaves, reducing the over-utilization of nitrogen fertilizers.

Polynomial regression analysis demonstrated SPAD index significance for nitrogen doses at 45 and 90 DAT, in which the increasing doses made SPAD index raise, showing, respectively, maximum values at 44.94 and 51.32 at 45 and 90 DAT with $2.8 \mathrm{~g}$ per pot. (Figure $6 \mathrm{~B}$ ).

Aquino et al. (2006) studied the same cultivar that was carried out in this research with increasing nitrogen doses. It was found out a quadratic effect for SPAD index with maximum value at 45.4. This result was different from the present study, since there were increments for SPAD index when nitrogen doses were raised.

Increments for SPAD index throughout the crop cycle might be explained for its nitrogen disponibility from the real-time process of nutrient mineralization for the plants, taking into consideration the significative interrelation among the intensity of green color, chlorophyll content and $\mathrm{N}$ concentration in leaves (Oliveira et al., 2017; Aquino et al., 2006; Pôrto et al., 2011).

In this way, it is notable that plant nutrient availability, either applied through basal dressing fertilizers or through fertigation, contributed successively not only for SPAD index increment, but for other pigments that took part in the process of the photosynthesis evaluated.

(B)

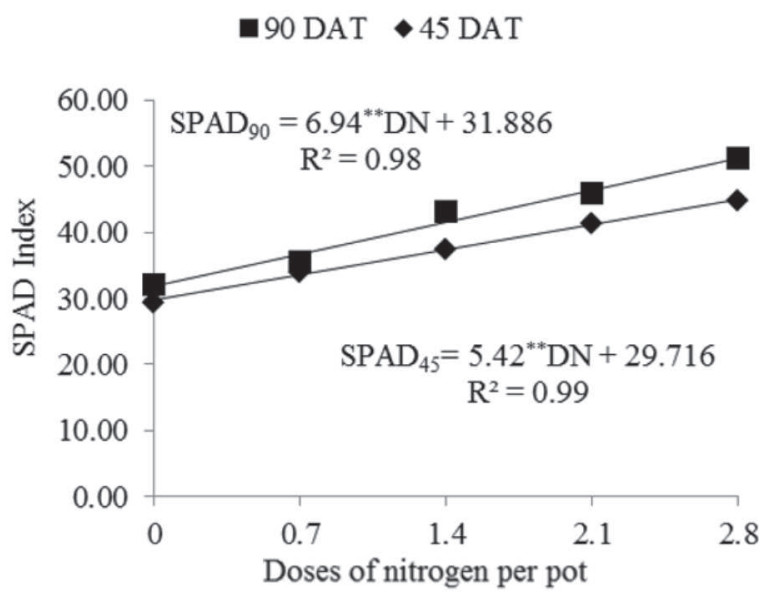

Figure 6: SPAD index in beet plants under kinds of basal dressing fertilization (A) and nitrogen doses applied through fertigation (B) at 45 and 90 DAT and SPAD index at 45 DAT. for cv. 'Early Wonder' (Beta vulgaris L). Equal letters do not differ statistically according to Tukey's test ( $\mathrm{p}<0.05)$. 


\section{CONCLUSIONS}

Organo-mineral fertilization (humus + NPK) promoted greater efficiency for photosynthetic pigments when compared with organic fertilization (humus) and with plants without fertilization (control).

The increasing nitrogen dose up to $2.8 \mathrm{~g}$ per pot promoted the greatest increments for the chloroplastid pigments.

Nutrients were absorbed by the plants and the humus and humus + NPK treatments supplied the nutritional demands during the beet cultivation cycle.

\section{ACKNOWLEDGEMENTS, FINANCIAL SUPPORT AND FULL DISCLOSURE}

The authors would like to thank CNPq and CAPES for the financial support and for granting scholarship for the experiment and research.

The authors have not declared any conflict of interests.

\section{REFERENCES}

Aquino LA, Puiatti M, Pereira PR, Pereira FH, Ladeira IR \& Castro MR (2006) Produtividade qualidade e estado nutricional da beterraba de mesa em função de doses de nitrogênio. Horticultura Brasileira, 24:199-203.

Araujo AV, Brandão Junior DS, Ferreira ICPV, Costa CA \& Porto BBA (2013) Desempenho agronômico de variedades crioulas e híbridos de milho cultivados em diferentes sistemas de manejo. Revista Ciência Agronômica, 44:885-892.

Armond C, Oliveira VC, Gonzalez SDP, Oliveira FER, Silva RM, Leal TTB, Reis AS \& Silva F (2016) Desenvolvimento inicial de plantas de abobrinha italiana cultivada com húmus de minhoca. Horticultura Brasileira, 34:439-442.

Barreto CR, Zanuzo MR, Wobeto C \& Rosa CCB (2013) Produtividade e qualidade da beterraba em função da aplicação de doses e nitrogênio. Revista Brasileira Multidisciplinar, 16:145-158.

Bonfim-Silva EM \& Monteiro FA (2010) Nitrogênio e enxofre na adubação e em folhas diagnósticas e raízes do capim braquiária em degradação. Revista Brasileira de Zootecnia, 39:1641-1649.

Bonfim-Silva EM, Paludo JTS, Sousa JVR, Freitas Sousa HH \& Silva TJA (2015) Development of safflower sujected to nitogen rates in cerrado soil. American Journal of Plant Sciences, 6:21362143 .

Cavalcante LF, Dias TJ, Nascimento R \& Freire JLO (2011) Clorofila e carotenoides em maracujazeiro-amarelo irrigado com águas salinas no solo com biofertilizante bovino. Revista Brasileira de Fruticultura, 33:699-705.

Costa ZVB, Neto PD, Andrade R, Santos JGR \& Farias AA (2008) Crescimento vegetativo do maracujazeiro-amarelo em diferentes tipos e dosagens de biofertilizantes na forma líquida. Revista Verde de Agroecologia e Desenvolvimento Sustentável, 3:116122 .

Embrapa - Empresa Brasileira de Pesquisa Agropecuária (2013) Sistema brasileiro de classificação de solos. Rio de Janeiro, Embrapa. 412p.

Ferreira DF (2014) Sisvar: a computer statistical analysis system. Ciência e Agrotecnologia, 35:1039-1042.
Ferreira TA, Silva EHC, Ribeiro MMC, Chaves PPN \& Nascimento IR (2012) Acúmulo de clorofila e produção de biomassa em hortelã-verde sob diferentes níveis de adubação orgânica. Revista Verde de Agroecologia e Desenvolvimento Sustentável, $7: 41-45$

Figueiredo Neto A, Oliveira SB, Lima MS, Amorim MR \& Figueiredo RMC (2011) Influência de composto orgânico nas características físico-químicas de cenoura "Brasília" no município de Petrolina (PE). Revista Semiárido de Visu, 1:03-09.

Filgueira FAR (2008) Novo manual de olericultura: Agrotecnologia moderna na produção e comercialização de hortaliças. $2^{a}$ ed. Viçosa, UFV. 421p.

Leonardo FAP, Pereira WE, Silva SM \& Costa JP (2013) Teor de clorofila e índice SPAD no abacaxizeiro cv. Vitória em função da adubação nitrogenada. Revista Brasileira de Fruticultura, $35: 377-383$.

Marenco RA \& Lopes NF (2009) Fisiologia vegetal: fotossíntese, respiração, relações hídricas e nutrição mineral. $3^{\mathrm{a}}$ ed. Viçosa, UFV. 486p.

Marenco RA, Nascimento HCS \& Magalhães NS (2014) Stomatal conductance in Amazonian tree saplings in response to variations in the physical environment. Photosynthetica, 52:493-500.

Oliveira RJP, Gatiboni LC, Brunetto G, Miquelluti DJ \& Valicheski RR (2017) Resposta da beterraba a adubação com nitrogênio enxofre e micronutrientes em um Cambissolo Háplico. Horticultura Brasileira, 35:63-68.

Persegil EO (2012) Recomendação de adubação nitrogenada para a cultivar de algodoeiro FMT 701 com base na leitura de clorofila IDF. Dissertação de Mestrado. Universidade Estadual Paulista, Ilha Solteira. 52p.

Pôrto ML, Puiatti M, Fontes PCR, Cecon PR, Alves JC \& Arruda JÁ (2011) Índice SPAD para o diagnóstico do estado de nitrogênio na cultura da abobrinha. Horticultura Brasileira, 29:311315 .

Sant'ana EVP, Santos AB \& Silveira PM (2010) Adubação nitrogenada na produtividade. leitura spad e teor de nitrogênio em folhas de feijoeiro. Pesquisa Agropecuária Tropical, 40:491496.

Sediyama M, Santos MR, Vidigal SM \& Salgado LT (2011) Produtividade e exportação de nutrientes em beterraba cultivada com cobertura morta e adubação orgânica. Revista Brasileira de Engenharia Agrícola e Ambiental, 15:883-889.

Silva ALP, Silva AP, Souza AP, San-tos D, Silva SM \& Silva VB (2012) Resposta do abacaxizeiro 'Vitória' a doses de nitrogênio em solos de tabuleiros costeiros da Paraíba. Revista Brasileira de Ciência do Solo, 36:447-456.

Silva CRM \& Silveira MHD (2012) Fertirrigação da cultura do rabanete com diferentes dosagens de nitrogênio. Enciclopédia Biosfera, 8:946-953.

Silva MA, Santos CM, Vitorino HS \& Rhein AFL (2014) Pigmentos fotossintéticos e índice SPAD como descritores de intensidade do estresse por deficiência hídrica em cana-de-açúcar. Bioscience Journal, 30:173-181.

Singh V, Singh B, Singh Y, Thind HS \& Gupta R K (2010) Need based nitrogen management using the chlorophyll meter and leaf colour chart in rice and wheat in South Asia: a review. Nutrient Cycling Agroecosyst, 88:361-380.

Spagnol WA, Park KJ \& Sigrist JMM (2006) Taxa de respiração de cenouras processadas e armazenadas em diferentes temperaturas. Ciência e Tecnologia de Alimentos, 26:550-554.

Streit NM, Canterle LP, Canto MWD \& Hecktheuer LHH (2005) The chlorophylls. Ciência Rural, 35:748-755.

Rev. Ceres, Viçosa, v. 66, n.6, p. 460-469, nov/dec, 2019 
Taiz L \& Zeiger E (2013) Fisiologia vegetal. 5a ed. Porto Alegre, Artmed. 954p.

Tivelli SW, Factor TL, Teramoto JRS, Fabri EG, Moraes ARA, Trani PE \& May A (2011) Beterraba: do plantio à comercialização. Campinas, Instituto agronômico. 45p. (Boletim técnico, 210).

Trani PE, Cantarella H \& Tivelli SW (2005) Produtividade de beterraba em função de doses de sulfato de amônio em cobertura. Horticultura Brasileira, 23:726-730.
Trani PE, Terra MM, Tecchio MA, Teixeira LAJ \& Hanasiro J (2013) Adubação Orgânica de Hortaliças e Frutíferas. Campinas, IAC. $16 \mathrm{p}$.

Whitham FH, Blaydes DF \& Devlin RM (1971) Experiments in plant physiology. New York, Van Nostrand Reinhold. 254p. 